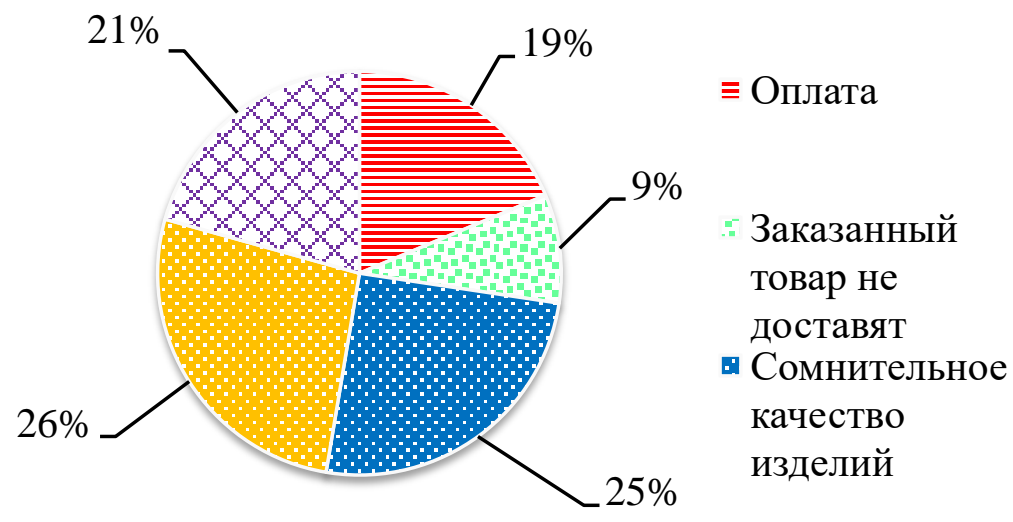

Рис. 2. Сомнения при покупках в интернет-магазине

Для удержания клиента необходимо установить максимальное доверие. Так как для потребителей важно качество покупаемых изделий, следует осуществлять контроль над выпуском продукции, а также давать на сайте магазина максимально подробное описание товара с фотографией, для того, чтобы ожидания клиента совпадали с реальностью. Поскольку для некоторых потребителей важна покупка без предоплаты, необходимо поместить информацию о том, что оплата может быть при получении, если это возможно. Основная часть опрошенных ориентируется на ценовой диапазон, таким образом, необходимо указывать реальные цены на товары, проводить регулярно мониторинг цен конкурентов, в случае если цены интернет-магазина выше, описать подробно преимущества данного товара и по возможности делать скидки. Люди из отдаленных районов часто интересуются доставкой, об этом тоже желательно информировать на основной странице сайта.

На самом деле, существует большое количество возражений, которые периодически возникают у клиентов. Именно благодаря им, интернет-магазин может понять, как нужно развиваться дальше.

Проведенное исследование подтверждает тот факт, что с ростом рынка электронной торговли онлайн-покупатель более грамотен, чем пару лет назад. И только те интернет-магазины, которые стремятся уделять должное внимание требованиям клиентов, будут иметь весомые преимущества перед конкурентами.

$$
* * *
$$

1. Юзабилитиинтернет-магазина: типичные ошибки, методы увеличения конверсии и рекомендации по улучшению [Электронный ресурс]. https://www.insales.ru/blogs/university/yuzabilitiinternetmagazina (дата обращения: 13.01.2018)

2. Сафронова Н.Б. Корнеева И.Е. Маркетинговые исследования. М.: Дашков и К, 2013. - 296 с.

3. Березин И.С. Маркетинговые исследования: Инструкция по применению. Люберцы: Юрайт, 2012. -383 c.

4. Носова Н.С. Конкурентная стратегия компании, или маркетинговые методы конкурентной борьбы. М.: Дашков и Ко, 2013. - 256 с.

\title{
Кониболоцкая А.А. Система управления рисками на предприятиях
}

Томский государственнылй университет (Россия, Томск)

doi:10.18411/spc-8-03-2018-21

idsp: 000001:spc-8-03-2018-21

Управление рисками - это систематический процесс выявления и оценки рисков компании с последующим принятием мер по их предотвращению или защите компании от них. Суть риск-менеджмента прежде всего заключается в управлении соотношением 
риска и рентабельности, следовательно, этот процесс помогает добиться значительных успехов, сбалансировать потенциальную прибыль и избежать дорогостоящих ошибок. Согласно содержанию стандарта ИСО 9001-2015, риск - ориентированное мышление является неотъемлемой частью плана стратегического развития компании, что повлияло на повсеместное внедрение системы ERM - система риск-менеджмента в масштабе предприятия [1]. Система управления рисками - это общесистемный подход, направленный на внедрение программ контроля и профилактики рисков по всей компании, что позволяет создать корпоративную культуру, способную справляться с рисками, связанными с быстро развивающейся бизнес-средой [2]. Главная цель заключается в обеспечении приемлемого баланса между риском и доходом, то есть использование системы в качестве предупреждающей меры, поскольку максимальная выгода может быть получена лишь в том случае, когда необходимо поддержать рост и прибыльность стабильной компании. Для улучшения системы разрабатываются специальные стратегии для снижения риска и системы мониторинга, которые предупреждали бы о потенциальных рисках. ERM - это технология будущего, которая позволяет извлекать уроки из предыдущих решений и динамически определять допустимые лимиты. Стандарт ИСО 31000 помогает организациям определить основные угрозы, оценить уязвимость компании перед рисками, определить методы и способы снижения этих рисков. Он призван «повысить вероятность достижения целей, улучшить выявление возможностей и угроз, а также эффективно распределять и использовать ресурсы для обработки рисков» [3]. Стандарт позволяет организациям сравнивать свои методы управления рисками с критериями, признанными во всем мире.

$$
\text { *** }
$$

1. ГОСТ Р ИСО 9001-2015 Системы менеджмента качества. Требования. [Электронный ресурс]. URL: http://docs.cntd.ru/document/1200124394

2. Фомичев A. H. Риск-менеджмент: учебник [Электронный ресурс]. - URL: http://velib.com/read_book/fomichev_andrejj_nikolaevich/risk_menedzhment/

3. Серия стандартов ISO 31000. Менеджмент рисков [Электронный ресурс]. - URL: https://intercert.com.ua/articles/regulatory-documents/311-iso-31000-risk-management

\section{Мызрова К.А., Филатова А.Д. \\ Мотивационная программа организации как инструмент развития лояльности персонала}

Ульяновский государственньй университет

(Россия, Ульяновск)

doi:10.18411/spc-8-03-2018-22

idsp: 000001:spc-8-03-2018-22

\section{Аннотация}

В данной статье рассмотрена актуальная на данный момент проблема формирования мотивационной программы организации как одного из самых эффективных и действенных инструментов лояльности персонала к организации. Мотивационная программа - комплекс мероприятий, стимулирующих персонал не только к работе, за которую платят, а прежде всего, активное желание работать именно в этой организации, к получению высоких результатов в своей деятельности и эффективности деятельности организации, формировании и развитию лояльности персонала к организации.

Ключевые слова: мотивация, мотивационная среда, мотивационная программа, лояльность персонала.

Преимущества компании, персонал которой лоялен, бесспорны. Именно персонал сможет упрочнить лидерские позиции организации на рынке, а для того, 